\title{
Quality of Practice Teaching Assignments as Experienced by Student Teachers of Silliman University
}

\author{
Batchiba R. Lacdo-o \\ Silliman University, Dumaguete City, Philippines \\ batchibarlacdo-o@su.edu.ph \\ https://orcid.org/0000-0003-4468-8516
}

\begin{abstract}
This paper compared the on-campus and off-campus practice teaching experience of 49 baccalaureate students in Elementary and Secondary Education of Silliman University College of Education. A self-administered questionnaire, the revised Student Teacher Assessment on the Silliman University Student Teaching Program, was the main data gathering instrument used. The Wilcoxon Matched-Pairs Rank Test showed that there was no significant difference in the student teachers' ratings of their oncampus and off-campus experiences. The same findings were noted on the challenges they have encountered and the recommendations they have posited, namely: classroom management and mentors' support and relationship. Further, the findings revealed that classroom management and mentors' support and relationship were their top two challenges. The student teachers strongly recommended that support for student teaching be improved especially in terms of mentors' support and scheduling. In addition, they strongly recommended that they are pre-observed by their supervisors before their final student teaching demonstration.
\end{abstract}

Keywords: Education, Student Practice Teaching, Comparative Research Design, Silliman University, Dumaguete City, Philippines

Date Submitted: January 7, 2019

Date Revised: July 7, 2019

Date Accepted: July 25, 2019

\subsection{Introduction}

In 1996, the Commission on Higher Education (CHED) granted the Teacher Education Department of the College of Education of Silliman University (SU) the recognition as a Center of Excellence (SU College of Education Student Handbook, 2017), and such distinction continues to be upheld up to the present. The college is committed 
to providing a holistic education through the integration of general and professional education courses with its practicum or practice teaching under the Student Teaching Program. Practice teaching is an integral part of any teacher education curriculum since it is a venue for pre-service teachers to apply theories and principles learned in the real classroom setting.

However, practice teaching could be a big challenge to the student teachers in the Teacher Education Program because the students are not yet fully prepared for actual classroom teaching (Haigh, Pinder \& McDonald, 2006). Starkey and Rawlins (2012) note that these student teachers still need to be well-monitored, supervised, and guided by their supervising teachers. Through constant monitoring and guidance from the latter, these students would learn how to handle and manage not just their daily lessons but their students and their classrooms as well. Thus, Tuli and File (2009) describe practicum teaching of pre-service teachers as the "most important part of the teacher education program" (p. 109).

The Silliman University Student Teaching Handbook and Portfolio (2017) define practice teaching as the last phase of the students' pre-service education wherein a student teacher is immersed in the actual teaching-learning situation, both on-campus and off-campus, and ancillary services (p. 1). Pre-service teachers or would-be teachers assume dual roles - the role of being a learner and a teacher. Such dual role may create tension because these pre-service teachers are subject to assessment by a variety of people from the university, and from the schools they were assigned to (Naylor, 2015). However, practice teaching affords student teachers to apply theory to the actual teaching and learning environment (Foncha, Abongdia \& Adu, 2015; Naylor, 2015). Such learning environment could be on-campus, and/or off-campus.

On-campus assignment of student teachers means their placement in any of the departments of the Silliman University School of Basic Education, which is the laboratory school for both the elementary and secondary student teachers. The General Education and Special Education majors (BEEd) were assigned at the elementary school while the secondary education (BSEd) student teachers were deployed at the high school in their various areas of specializations during the first semester of the school year. The assignment ended with a Final Student Teaching Demonstration (FSTD) as a major requirement of the Student Teaching course.

Meanwhile, off-campus assignment refers to the placement of student teachers in the public schools in Dumaguete City and the Province of Negros Oriental. These public laboratory schools cater not only student teachers from Silliman University but also student teachers from other colleges and universities in Dumaguete City. A Memorandum of Agreement (MOA) was forged between Silliman University and the Department of Education (DepEd) to ensure the quality and sustainability of the program.

A related study conducted by Hodge, Davis, Woodard, and Sherrill (2002) compared the effects of two practicum types (off-campus and on-campus) on physical education students' attitudes and perceived competence toward teaching school-aged students with physical and mental disabilities, who reported no significant difference between off-campus and on-campus on posttest attitude and perceived competence measures.

Expectedly, varied experiences await students in practice teaching because of 
a different standard policy of pre-service teacher training programs, like for example, between the Bachelor of Science in Education (BSEd) major in English and Bachelor of Arts (BA) in English programs (Ulla, 2016). While BSEd English is concentrated on developing professional teachers for secondary schools, BA English is focused on developing not just teachers but professionals with exceptional communication skills. Ulla (2016) in his study also noted that student teachers needed to improve their classroom management and to teach confidently as well as enrich their teaching resources.

Studies of Beare et al. (2015) and Allen (2009) concluded that pre-service teachers were satisfied with their preparation for teaching because it was authentic and real. Furthermore, Allen (2009) emphasized in his study that successful practicum included experiences that are developmentally sequenced and that there existed congruence between student teachers' and mentors' beliefs and values about teaching. Other authors like Caires, Almeida, and Vieira (2012) showed that practice teaching was highly regarded by a majority of students as they considered the theoretical aspects of their education important to future teachers. Moreover, the students perceived the institutional-based supervisors of the practicum to have provided them with the most significant support alongside their peers and school-based mentors. On the same study, they similarly found how students valued the knowledge and skills they acquired from practice teaching which improved their sense of efficacy because of the support provided to them by their supervisors.

On the other hand, Hasher et al. (2004 cited in Adu-Yeboah et al., 2018) and Hormenu (2014) argue that the quality of student teachers' learning during on-campus and off-campus practicum varies as it depends on the quality of feedback from mentors. Both studies recommended that both on and off-campus practicum should conduct orientations to heads of institutions and mentors on their role of teacher preparation. This recommendation is consistent with the study of Abas (2016) who suggested orientation as a means of improving off-campus practicum.

However, the student teachers also expressed some difficulties during practice teaching periods such as stress, sense of weariness, and vulnerability although these problems differed depending on their assigned schools because of the availability of resources and opportunities. Some challenges in actual teaching revolved around classroom management resulting in the amount of confidence they have developed, the quality of teaching resources available to them, and the teaching strategies they employed (Ulla, 2016). Disciplining students was most challenging to student teachers, but despite the anxiety, they still considered practice teaching to have allowed them to merge theory and practice, hone their teaching and management skills, and cope with the demands of multi-tasking in a classroom setting.

The gap in knowledge which this author wishes to fill is the lack of literature comparing off-campus and on-campus assignments of student teachers as well as the very minimal studies on assessing the effectiveness of student teaching as a basic preparation of pre-service teachers. Silliman University Student Teaching Program is unique since student teachers are required to do practice teaching for two semesters, instead of only one. At the time when this study was conducted, the Silliman student teaching during the first semester was on-campus, at the Basic Education Department; 
then for the second semester, the student teachers were assigned off-campus, in DepEd schools, and other private schools in the city. Student Teaching in most Teacher Education Institutions is conducted for one semester only, which could explain the absence of comparative literature since most TEls have only off-campus student teaching.

Given this background, this paper primarily aimed to find out how the student teachers, classified by sex and specialization, rated their experiences during their oncampus and off-campus student teaching experience and if a significant difference existed between the two assignments. This paper also examined the challenges or problems they have encountered and the recommendations they have posited to sustain or improve the Student Teaching Program of the College. The recommendations they have given during their on-campus and off-campus practice teaching assignments were compared.

\subsection{Framework of the Study}

The adult learning theory of Knowles (1984) holds the belief that adults learn differently from children. As a person matures, his or her readiness to learn increases, as experience broadens tremendously. Motivation to learn among adults is internal and is more interested in learning experiences that have immediate relevance to their jobs or lives. Pre-service teachers are therefore considered as adult learners, who are transitioning to become professional teachers, and should be allowed by mentors and supervisors to discover for themselves competencies and strategies they need to develop in order to succeed. However, even though they are self-directed learners, student teachers still need guidance from their supervisors and mentors especially during the initial learning phase, where mistakes could happen.

Meanwhile, the cultural perspective theory of Vygotsky (cited in Corpuz et al., 2010) suggests that human activities are rooted in social participation and learned not in isolation but with the assistance of others. Social interaction is seen as a critical influence in the learning potential of school-based mentoring where the mentor explains, models, assists, gives directions, and provides feedback to the learner, in particular the student teacher. Accordingly, peers, on the other hand, cooperate and collaborate, thus enriching the learning experience in student teaching assignment which may be on-campus and off-campus. Moreover, Vygotsky explains that culture plays a major role in the cognitive development and learning of learners because it provides a wide range of hands-on learning activities rather than passive listening.

Another model, called the Apprenticeship Model, presents a context wherein a more experienced person (the mentor or supervisor) works with a less experienced person (Lunt et al., 1992; Clutterbuck, 1985). This model recognizes mentoring as the center of the apprenticeship system and emphasizes the "power-dependency status" which refers to the expertise of the mentor and the dependency of the mentee (Clutterbuck, 1985 in Rice, 2004). Clutterbuck (2013) adds that the American version of mentoring cites mentors who help their mentees reflect and make choices about the future. He stated in his book that informal mentoring is more effective than the formal 
ones, although getting the best from a mentoring scheme involves building in the best aspects of both formal and informal approaches, where the former very frequently result to successful informal ones.

David Kolb's (1984) Experiential Learning Theory holds that experience is the source of learning and development, where the word "experience" has its intellectual origin from the experiential works of Lewin, Piaget, Dewey, Freire, and James. The combined works form the basis of Kolb's theory, which is a unique perspective on learning and development. This theory, known as experiential learning, is a multi-linear model of adult development, consistent about how one naturally learns, grows, and develops recognizing the critical role of experience in the learning process.

Kolb's four-stage learning cycle begins with concrete experience, which means it begins with tasks to be done with active involvement by the learner(s) as key to learning. One cannot learn unless the learner does the skill personally and not just merely observing or watching someone doing the task.

The second stage is reflective observation, where the learner takes a time-out and steps back and reviews what has been done. Here, it is necessary for learners to receive and give feedbacks from others. Critical to learning is to communicate with others and to ask as many questions as possible. These are done through writing diaries and completing learning logs, and engaging oneself in quiet thinking time.

The third stage is abstract conceptualization, which involves making sense of what has transpired, interpreting events, and understanding relationships. The learners at this stage reflect on what they already know, present models, or draw some theories to explain phenomena, entertain ideas from colleagues, examine previous observations, and the like.

The final stage of the learning cycle is active experimentation, where learners put what they have learned into practice, making sure that learners are engaged in contexts which are relevant and meaningful to them. This is the part where learning is applied to real-world situations, made possible through projects, fieldworks, laboratories, case studies, simulations, and the like.

In synthesis, Figure 1 shows that the support and the challenge extended by a mentor to a mentee in student-teaching are necessary ingredients in learning the skills of a competent professional teacher. The quality of mentor-student teacher interaction is considered critical to the learning not only of skills but also of habits, attitudes, and values necessary to develop that love to teach learners who come from various socioeconomic backgrounds. Student teaching is considered as an experiential learning, where student teachers handle classes, reflect on what they are learning, and work closely with their mentors and other student teachers in giving feedback and getting better ideas about how to better their craft. 


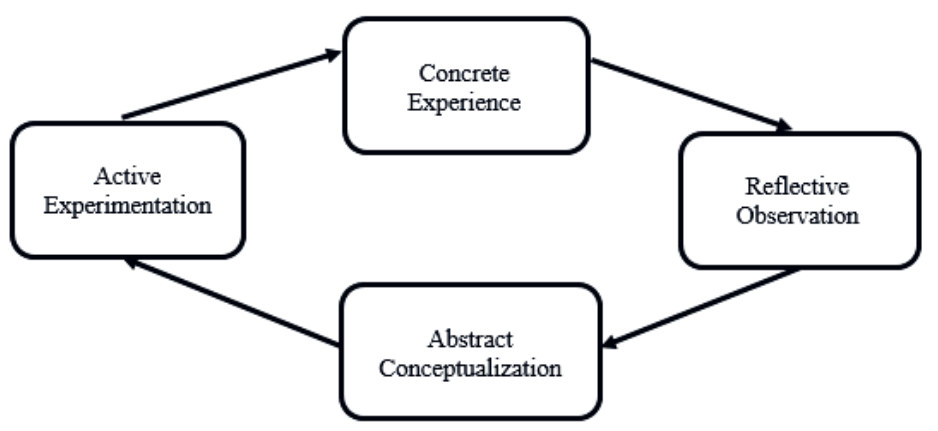

Figure 1. The Kolb Learning Cycle (Kolb, 1984)

Finally, the learner-centered micro-teaching model (also known as On-Campus Teaching Practice or OCTP), which was utilized by Kilic (2010 cited in Adu-Yeboah \& Yaw Kwah; 2018) in an experimental study found out that using such model increases student teachers' skills and positive change in attitudes toward pupils. The model utilizes recording of teaching sessions in order to get constructive feedback from peers and/ or students to help improve teaching techniques. It includes lesson plan preparation, choosing appropriate teaching/learning resources, managing time effectively, applying appropriate assessment techniques, and speaking in front of a group. This model, although designed for campus-based practicum (on-campus), may still be applicable to the off-campus teaching. However, according to Adu-Yeboah and Yaw Kwaah (2018), the quality of student teachers' learning during campus-based practicum depends on the quality of feedback from mentors, effective practicum management, and the quality of reflections done by student teachers. Likewise, Abas (2016) recommended that whether student teaching experiences are desirable or not, there is a need for student teachers to be aware of the adjustments from on-campus experience to off-campus and to reflect on those experiences.

\subsection{Methodology}

This study employed a descriptive-comparative research design to determine the student teachers' quality of experience during their on-campus and off-campus student teaching as well as whether a significant difference exists between these two assignments of the respondents. All student teachers of Silliman University who graduated in March 2017 and who were attending review classes for the Licensure Examination for Teachers (LET) were the participants of this study. They were classified by sex and course for comparative analysis relative to their on-campus and off-campus teaching assignments.

To get rid of the occurrence of the so called, "garbage in garbage out" phenomenon, the questionnaire used in the collection of data pertaining to the student teachers' on-campus and off-campus experiences were subjected to both qualitative review and quantitative analysis. The qualitative review was undertaken by the 
student teacher supervisors in order to determine its relevance and appropriateness. The quantitative analysis, on the other hand, was done by subjecting it to reliability testing using a group of respondents who were similarly situated to the final group of respondents and computing the data collected using Cronbach Alpha. The analysis yielded a reliability coefficient of 0.76 , a figure which is higher than the least acceptable value of 0.60 (Nunnally, 1978).

Based on the result, it can be safely said that it is reliable. The questionnaires were then distributed to the 49 student teachers who agreed to participate in the study after signing on the informed consent and after having been assured of confidentiality in the handling of data.

The instrument used in this study deals with both mentoring and supervising of student teachers, but more on the latter. Mentoring is the process by which an assigned mentor assists, guides, and critiques the student teacher assigned under his or her tutelage. Supervision, on the other hand, includes the preparations conducted to qualify the student teachers for the tasks like pre-student teaching demonstration, orientations, the assignment of specialists or experienced panelists to provide helpful feedback during the final student teaching demonstration. It includes conducting conferences with student teachers when necessary, conducting pre-observations to ensure that student teachers perform according to expectations, requiring student teachers to submit weekly journals and the required portfolio, and monitoring student teachers' attendance, grades, and behaviors.

Quality in student teaching assignment, as reflected in the research tool, means that the student teachers had clear expectations of the program, had sufficient preparation to become student teachers, were assigned to qualified mentors who provided meaningful feedback to student teaching performance, and had specialists giving feedback during the final student teaching demonstration post-conferences. In addition, a comprehensive assessment tool was used to evaluate student teaching performance, and a harmonious relationship existed between the supervisors and mentors.

In analyzing the data, weighted mean was used in determining the quality of the student teachers' experiences. Wilcoxon Matched Test was utilized to ascertain the extent of difference between respondents' on-campus and off-campus student teaching experiences. Moreover, Mann-Whitney $U$ test was used in finding out if a significant difference exists between the two sets of ratings when grouped according to sex and area of specialization.

Meanwhile, participants' qualitative responses to the open-ended questions on the second part of the assessment tool were converted to quantitative data for analysis to validate the quantitative ratings in the first part. Themes from the qualitative responses were determined by adopting Van Manen's (1997) approach of uncovering thematic aspects using the highlighting approach. The researcher read the text several times and asked "What statements or phrases seem particularly essential about the experience" and the line-by-line method on which the researcher looked at every single sentence and asked, "What does this sentence or phrase reveal?" Also, the qualitative data gathered from this study were based on the recommendations of students to improve the student teaching program. 


\subsection{Results}

Profile of the student teachers. Out of the total 49 student teachers who voluntarily participated in the study, $42(86 \%)$ were female, and $7(14 \%)$ were male, which seemingly supported the stereotype that those who pursue the teaching career are mostly females and only a few are males. Specifically, among the 26 elementary education student teacher respondents, 15 (53.06\%) were General Education majors, $10(38.46 \%)$ were Special Education majors while only 1 (3.85\%) was a Pre-School major. Meanwhile, the 23 secondary school student teacher respondents (46.94\%) were composed of 12 English majors, eight MAPEH majors, two Biological Sciences majors, and one Social Studies major.

Quality of on-campus and off-campus experiences. Table 1 showed that all the ratings in both off-campus and on-campus are within the verbal description 'strongly agree'. This indicated that their mentors in both student teaching exposures have provided them the opportunity to reflect on what makes a competent teacher especially during post conferences after their final student teaching demonstration where feedbacks have been given. Mentors' feedbacks were found to be useful since these were based on the criteria stipulated in the assessment form prepared by the college. The student teachers adhered to the notion that they were given ample preparation in terms of knowledge and skills germane to teaching by the faculty of their college prior to their actual exposure into the classroom. Another factor which is of substantial contribution to satisfying experience they have had in their student experience is the alignment of their area of specialization with that of the mentor.

A closer look at the aggregate means of Table 1 showed that a slight difference does exist. However, it could not specifically be said whether such difference is significant; hence, Wilcoxon's test of difference was performed, and the results are shown in Table 2. The 12 pairs of ratings have a Wilcoxon's value of 42 and a $p$ value of 0.103 . These values give credence to the conclusion that the student teachers' teaching experiences in the off-campus and on-campus do not significantly differ. As for a significant difference to exist at 0.05 level of significance, a $p$ value equal to or lesser than 0.05 must be observed. The absence of a significant difference in the assessment of their on-campus and off-campus experiences can be attributed to their preparedness to carry on the task, their positive relationship with their mentors, to the positive benefit they acquired from the experience, and to the orientation to the general culture of the school they were assigned to, whether off-campus or on-campus. 
Table 1. Student Teachers' On-And Off-Campus Ratings

\begin{tabular}{|c|c|c|}
\hline \multirow{2}{*}{ Statements } & \multicolumn{2}{|c|}{ Mean Ratings } \\
\hline & On-Campus & Off-Campus \\
\hline $\begin{array}{l}\text { Being a student-teacher provided me the opportuni- } \\
\text { ty to reflect on what makes a competent teacher. }\end{array}$ & 3.29 & 3.55 \\
\hline $\begin{array}{l}\text { The post-conference during the final student teach- } \\
\text { ing demonstration provided me the opportunity to } \\
\text { reflect on the observations and feedback given on } \\
\text { my performance as a student teacher. }\end{array}$ & 3.59 & 3.82 \\
\hline $\begin{array}{l}\text { I learned from the feedback and comment given by } \\
\text { the student teaching supervisors and the subject } \\
\text { area specialists during the post conference of my } \\
\text { final student teaching demonstration. }\end{array}$ & 3.6 & 3.73 \\
\hline $\begin{array}{l}\text { The assessment form used for evaluating me as a } \\
\text { student teacher was comprehensive and specific. }\end{array}$ & 3.66 & 3.67 \\
\hline $\begin{array}{l}\text { I had sufficient preparation to become a student } \\
\text { teacher for this semester. }\end{array}$ & 3.27 & 3.8 \\
\hline $\begin{array}{l}\text { The student teaching program expectations were } \\
\text { clear to me. }\end{array}$ & 3.82 & 3.86 \\
\hline $\begin{array}{l}\text { The final student teaching demonstration post con- } \\
\text { ference with the student teaching supervisors gave } \\
\text { insights on how to enhance my knowledge and skills } \\
\text { as a future teacher. }\end{array}$ & 3.61 & 3.65 \\
\hline $\begin{array}{l}\text { The student teaching supervisors from Silliman } \\
\text { University had maintained a harmonious working } \\
\text { relationship with my student teaching mentor. }\end{array}$ & 3.51 & 3.47 \\
\hline $\begin{array}{l}\text { I believe that the post conference was among the } \\
\text { best features of the student teaching program of } \\
\text { Silliman University. }\end{array}$ & 3.80 & 3.78 \\
\hline $\begin{array}{l}\text { Subject specialists were present during my final stu- } \\
\text { dent teaching demonstration to give their feedback. }\end{array}$ & 3.78 & 3.76 \\
\hline $\begin{array}{l}\text { I was assigned to a student teaching mentor based } \\
\text { on the latter's qualifications. }\end{array}$ & 3.59 & 3.64 \\
\hline $\begin{array}{l}\text { Feedback was encouraged and sufficiently given by } \\
\text { my student teaching mentor. }\end{array}$ & 3.76 & 3.67 \\
\hline Aggregate & 3.60 & 3.70 \\
\hline
\end{tabular}

Legend: 1.00-1.74=Strongly Disagree; 1.75-2.49=Disagree;2.50-3.24=Agree; 3.25-4.0=Strongly Agree

The 12 pairs of ratings have a Wilcoxon's value of 42 and a p value of 0.103 . These values give credence to the conclusion that the student teachers' teaching experiences in the off-campus and on-campus do not significantly differ. For a significant difference to exist at 0.05 level of significance, the $p$ value must be equal to or lesser 
than 0.05. The absence of a significant difference in the assessment of their on-campus and off-campus experiences can be attributed to their preparedness to carry on the task, their positive relationship with their mentors, to the positive benefit they acquired from the experience, and to the orientation to the general culture of the school they were assigned to, whether off-campus or on-campus.

Table 2. Difference in the students' ratings during their on-campus and off-campus experiences

\begin{tabular}{|c|c|c|c|c|}
\hline \multirow{2}{*}{ Ns } & \multicolumn{2}{|c|}{ Mean Rating } & \multirow{2}{*}{ w } & \multirow{2}{*}{ p } \\
\cline { 2 - 3 } & On-campus & Off-campus & & \\
\hline 12 & 3.60 & 3.70 & 42 & 0.103 \\
\hline
\end{tabular}

Note: Wilcoxon Matched Pairs Rank Test=42, p-value=0.103. For a significant difference to exist, the $p$-value must be less than the alpha at 0.05 .

Rating of experiences of student teachers according to sex and course. The data in Table 3 point to the fact that no significant difference exists in the experiences of the female and male student teachers. This is exemplified in the $p$ value being greater than 0.05 . This implies that both sexes enjoyed the same experience both on-campus and off-campus student teaching. Though there is a 0.13 difference between the female and male mean scores in favor of the former, such has not reached the cut-off; hence, it means that both groups of student teachers are favorably trained to becoming fullfledged teachers.

The same was manifested in the comparison of ratings between the BEED and BSED majors. The data indicated that neither group is given a more preferential consideration. This is another favorable phenomenon as fairness takes preponderance irrespective of major area of specialization. Same with that in the comparison in terms of sex, a difference in the mean score (0.09) between the BEED and BSED does not exist in favor of the former; however, such has not reached the significant level. In a nutshell, the male and female student teachers, whether they are BEED or BSED majors have signified having a favorable student teaching experience.

Table 3. Difference in student teaching experience of student teachers classified by sex and course

\begin{tabular}{|c|c|c|c|}
\hline \multicolumn{2}{|c|}{ Mean Scores } & U & p-value \\
\hline Female & Male & & \\
\hline 3.69 & 3.56 & 128.5 & 0.219 \\
\hline BEED & BSED & & \\
\hline 3.71 & 3.62 & 247.5 & 0.412 \\
\hline
\end{tabular}

Challenges experienced by student teachers. Two themes emerged among the several challenges encountered by student teachers during their on-campus and 
off-campus assignments: classroom management and support of and relationship with their mentors. However, some of them shared that their mentors were exceptions because they showed their dedication, and they learned a lot with and from them. There were some mentors, however, who were not always around when they were teaching. They reported that, as a consequence, not enough feedback was given to them to improve their teaching skills. The mentors' lack of supervision may have caused the challenge of classroom management. Seemingly, the presence of the mentor in class when student teachers took over and classroom management were closely tied. Student teachers experienced that when the mentor left them, classroom management became a big challenge because the students or pupils became unruly. Perhaps some students did not take student teachers seriously because they did not consider them as "real" teachers, and they were without authority yet. This tendency may be due to the failure to make the students understand that the mentors of student teachers had given them responsibility over classroom management when the latter took over the classes.

Table 4. Challenges Encountered by Student Teachers during On-Campus and OffCampus Assignments

\begin{tabular}{|l|l|l|l|}
\hline \multicolumn{1}{|c|}{ Challenges Encountered } & On-Campus & \multicolumn{1}{c|}{ Off-Campus } & \multicolumn{1}{c|}{ Total } \\
\hline Classroom management & $11(22.45)$ & $10(20.41)$ & $21(21.43)$ \\
\hline $\begin{array}{l}\text { Support of and relationship with } \\
\text { mentors }\end{array}$ & $10(20.41)$ & $8(16.32)$ & $18(18.37)$ \\
\hline Lesson planning & $2(4.08)$ & $6(12.25)$ & $8(8.16)$ \\
\hline $\begin{array}{l}\text { Balancing student and teacher } \\
\text { roles }\end{array}$ & $3(6.12)$ & $4(8.16)$ & $7(7.14)$ \\
\hline Lack of teaching materials & $2(4.08)$ & $5(10.20)$ & $7(7.14)$ \\
\hline Class and subject assignment & $3(6.12)$ & $3(6.12)$ & $6(6.12)$ \\
\hline $\begin{array}{l}\text { Preparation prior to final demon- } \\
\text { stration }\end{array}$ & $3(6.12)$ & $1(2.04)$ & $4(4.08)$ \\
\hline Poor classroom condition & $2(4.08)$ & $6(12.25)$ & $8(8.16)$ \\
\hline No challenges & $13(26.53)$ & $6(12.25)$ & $19(19.40)$ \\
\hline \multicolumn{1}{|c|}{ Total } & $49(100)$ & $49(100.00)$ & $98(100.00)$ \\
\hline
\end{tabular}

The need for orientation and multiple observations. Although the student teachers rated the quality of their experiences in both on-campus and off-campus student teaching assignment as high which was close to the perfect rating of four, they also found the importance of the mentors and supervisors conducting multiple observations before the final teaching demonstration.

Overall, they unanimously agreed on the importance of conducting orientation among all involved before their deployment and holding pre-observations before the final student teaching demonstration. The Teacher Education of the College of Education conducted orientations for off-campus, while the laboratory or cooperating schools conducted the same for on-campus. Supervisors also conducted similar orientations 
to clarify roles and expectations and to give specific recommendations for student teachers to succeed. The same activity was conducted by the respective principals on school policies, expectations, and clarification of roles. The student teaching supervisors worked closely with the school principals and mentors, conducted pre-observations and visits as part of supervisors' routine, but there was a need to schedule them to avoid conflicts with other school activities such as classes, meetings, office work, and the like. The distance of the schools where the student teachers were assigned was one of the limitations noted. Nevertheless, supervisors still conducted visits, especially when requested by the principal, the mentor, or by the student teachers themselves.

Suggestions for an enhanced and sustained student teaching. The most prevalent recommendation was more on the support for student teachers by having the presence of the mentors during classes to coach and guide them. This suggestion would address the related challenges mentioned earlier, especially during their offcampus assignment. Another suggestion was to provide them more time for on-campus student teaching before sending them outside. This recommendation showed that the student teachers felt the need to extend student teaching beyond the duration of time that has been allotted for them.

There was also a clamor to have supervisors conduct pre-observation visits as some claimed of not being visited before their final student teaching demonstration. Exposing student teachers to challenging classes during on-campus assignments would make them more prepared for off-campus teaching. Because of the K-12 spiral progression approach, student-teachers who were science majors specifically suggested to align their curriculum to prepare them for it. They reiterated the need for student teachers to be given more time to teach before the final student teaching demonstration.

Moreover, the student teachers strongly suggested that teachers be briefed before their assignment as mentors in the student teaching program. They believed this would make the mentors aware that the student teachers still have classes in college along with their on-campus and off-campus assignments. They also suggested that mentors assigned to them be responsive to their needs, particularly during off-campus deployment. They reiterated the need for mentors to be always present to observe and provide them scaffolding instead of pressuring them.

\subsection{Discussion}

The findings of this study have debunked the belief that on-campus student teaching experience was always better than off-campus. Results showed that there was no significant difference between off-campus and on-campus student teaching experience. A possible reason for this was that the student teaching program expectations were clarified right from the very start for both assignments. Student teachers from both assignments likewise noted that the program have provided them opportunities to reflect on what makes a competent teacher. In addition, orientations and pre-observations have been conducted, regardless where they are assigned.

On the other hand, respondents reported that classroom management and 
support and relationship with mentors, have been found to be their first two top challenges, which was something to pay attention to, especially in student teaching preparation. Although their off-campus assignments offered a less favorable school environment (See "Others" in Table 4), where respondents noted poor ventilation, overcrowding of classes, dim lighting in most DepEd schools, these were still preferred over the more adequately-provided school facilities in the on-campus setting. Furthermore, this implied that the mentor-mentee relationship offered greater impact to student teaching than the physical school condition. This preference for a more informal mentor-mentee relationship was consistent with the study of Clutterback (2013), who found that informal mentoring was more effective than the formal ones.

Student teachers cited classroom management as a major challenge. Since the transition from being students to being teachers happen during student teaching, managing classes could be difficult because the inexperienced student teachers still lacked the necessary exposure to meet the rigors of classroom management. This was true to both off-campus and on-campus experiences although on-campus was slightly higher than the off-campus, which implied that there was more concern for classroom management during on-campus. Respondents may have found on-campus classroom management to be more challenging since the learners were more diverse, may have had higher incidents of parental involvement in school affairs, and may, at times, had more parents who questioned the quality of instruction under the student teachers.

\subsection{Conclusion}

The results of the study statistically showed that the quality of experiences of both on-campus and off-campus student teaching assignments are not different from each other. Nonetheless, they recommended for a more comprehensive orientation at the start of their student teaching, that the curriculum be improved to make them more aligned to the $\mathrm{K}-12$ program, and that supervisors conduct pre-observations prior to the final student teaching demonstration. In addition, high mentors' support for student teaching was recommended, and a thorough review of school schedules be done to give more priority to student teaching.

\subsection{Acknowledgment}

The Silliman University Faculty Development Grant managed by the University Research Center through Research Director Dr. Margaret Udarbe-Alvarez, funded this research. The assistance of Dr. Enrique Oracion, Dr. Pablito de la Rama, and Dr. Mary Ann Temprosa towards the completion of this paper is likewise highly appreciated. 


\section{REFERENCES}

Abas, M. (2016). Pre-service teachers' experience during off-campus observation: basis forlmproving the roles of teacher education institutions and cooperating schools. Journal of Education and Learning. Vol. 10 (2) pp. 187-202.

Adu-Yeboah, A. \& Yaw Kwaah, C. (2018). Preparing teacher trainees for field experience:Lessons from the on-campus practical experience in colleges of education in Ghana.Retrieved from: https://www.researchgate.net/publication/328549736. Preparing Teacher Trainees for Field Experience Lessons from the On-Campus Practical Experience in Colleges of Education in Ghana.

Allen, J. (2009). Valuing practice over theory: How beginning teachers re-orient their practice in the transition from university to workplace. Teacher and Teacher Education, 25, 647654.

Ashraf, M. (1999). Dictionary of Primary Education. A.P.H. Publishing Corporation, New Delhi.

Beare, P., et. al. (2012). Examination of alternative programs of teacher preparation on a single campus. Teacher Education Quarterly, 39 (4), 55-70. Retrieved from http://www/ teqjournal.org.

Brookfield, S. (1995) Adult learning: An overview international encyclopedia of education. Oxford: Pergamon Press.

Caires, S., Almeida, L., \& Vieira, D. (2012). Becoming a teacher: Student teacher's experiences and perceptions about teaching practice. European journal of teacher education, 35 (2), 163-178. http://dx.doi.org/10.1080/02619768.2011.643395.

Cleope, E., De La Rama, P., Temprosa, M., Bonior, G., Lacdo-o, B. \& Nasvik, E. (Ed. Team). (2016) Teachers on FIRE : Silliman University Student-Teaching Handbook and Portfolio, 3rd ed.

Clutterback, D. (2013). Mentoring and coaching. International Journal of Sports, Science \& Coaching. Volume 8 issue: 1 pages: 139-254. https://doi.org/10.1260/17479541.8.1.139.

College of Education. (2013). Silliman University College of Education Student Handbook. Silliman University, Dumaguete City.

Corpuz, B., Lucas, M. R., Borabo, H.G., \& Lucido, P. (2010). Child and adolescent development. Manila: Lorimar Publishing, Inc.

Daloz, L. (1986). Effective teaching and mentoring. San Francisco, Ca: Jossey-Bass Publishers.

Foncha, J., Abongdia, J.F., \& Adu, E. (2015). Challenges encountered by student teachers in teaching English language during teaching practice in East London, South Africa. International Journal of Educational Sciences. Volume 9, 2015 - Issue 2. Retrieved from https://doi.org/10.1080/09751122.2015.11890302 
Haigh, M., Pinder, H. \& McDonald, L. (2015). Practicum's contribution to students' learning to teach. A Paper Presented at the British Educational Research Association Annual Conference, University of Warwick, September 6-9, 2006.

Hodge, S., Davis, R., Woodard, R., Sherrill, C. (2002). Comparison of practicum types in changing pre-service teachers' attitudes and perceived competence. Adapted Physical Activity Quarterly, 2002, 19, 155-10. Human Kinetics Publishers, Inc.

Hormenu, T. (2014). Challenges and prospects of off campus practicum: the experience of the physical education student teacher. Retrieved from: https://www.researchgate.net/ publication/263973650

Knowles, M. (1984). The adult learners: A neglected species (3rd ed). Houston: Gulf Publishing. Retrieved from https://www.learning-theories.com/andragogy-adult-learning-theoryknowles.html

Kolb, D.A. (1984). Experiential learning: experience as the source of learning and Development. Englewood Cliffs, NJ: Prentice Hall. Retrieved on January 8, 2018 from http://www. learningfromexperience.com/images/uploads/process-of-experiential-learning.pdf

Moses, I., Admiraal, W. \& Berry, A. (2006). Gender and gender role differences in studentteachers' commitment to teaching. Social psychology of education, 19 (3), pp. 475-492. Retrieved on January 8, 2018 from https://link.springer.com/article/10.1007/s11218016-9340-3.

Naylor, D. (2015). Learning to teach: What pre-service teachers report. Edith Cowan University Research Online Theses: Doctorates and Masters Theses 2015.

Nunnally, J. (1978). Psychometric theory. New York: McGraw-Hill.

Starkey, L. \& Rawlins, P. (2012) Student teacher learning during practicum experience. Teacher Education Advancement Network Journal (TEAN), 4 (1). Retrieved June, 2017 from https://ojs.cumbria.ac.uk/index.php/TEAN/index

Stones E. \& Morris, S. (2006). The assessment of practical teaching. Educational research 14 (2). Pp. 110-119.

Tuli, F. \& File, G. (2009). Practicum experience in teacher education. Ethiopian journal of education and science. 5 (1). Pp. 107-116.

Ulla, M. (2016). Pre-service teacher training programs in the Philippines: The student teacher practicum teaching experience. EFL journal 1 (2) DOI: http://dx.doi.org/10.21462/elfj. vlij.vli3.23

VandenBos, G.R. (Ed.). (2010). Publication Manual of the American Psychological Association, 6th ed. Washington D.C. American Psychological Association.

Van Manen, M. (1990). Researching lived experience: Human science for an action sensitivepedagogy. Alhouse Press, Ontario. 